\title{
Effect of Different Types of Mulches on Growth and Yield of Black Turmeric (Curcuma caesia)
}

\author{
R. Chitra* , D. Janaki and P. Jansirani
}

Department of Spices and Plantation Crops, Horticultural College and Research Institute, Tamil Nadu Agricultural University, Periyakulam-625601, Tamil Nadu, India

*Corresponding author

\begin{tabular}{|c|c|}
\hline & A B S T R A C T \\
\hline $\begin{array}{l}\text { Black turmeric, } \\
\text { Mulching, Dry } \\
\text { grass, Rhizome } \\
\text { yield }\end{array}$ & \multirow{3}{*}{$\begin{array}{l}\text { The experiment was conducted at Horticultural College and Research Institute, } \\
\text { Periyakulam, Tamil Nadu during } 2019-20 \text { to study the effect of different mulches on } \\
\text { growth and yield of Black turmeric under drip irrigation condition. In this trial, } \\
\text { different organic mulches viz., paddy straw, dry grass, coir pith along with plastic } \\
\text { mulch were used as mulching material. A treatment without mulching was also treated } \\
\text { as control. The experiment was laid out in a randomized block design with four } \\
\text { replications. The results indicated that the plants mulched with dry grass recorded } \\
\text { maximum average plant height }(58.40 \mathrm{~cm}) \text { and number of leaves }(16.00) \text { as compared } \\
\text { to other mulches. In case of yield of turmeric also, the dry grass mulch gave maximum } \\
\text { fresh rhizome yield }\left(22.03 \mathrm{t} \mathrm{ha}^{-1}\right) \text { followed by mulching with paddy straw }(19.41 \mathrm{tha} \\
\left.{ }^{1}\right) \text {. }\end{array}$} \\
\hline Article Info & \\
\hline $\begin{array}{l}\text { Accepted: } \\
22 \text { June } 2020 \\
\text { Available Online: } \\
10 \text { July } 2020\end{array}$ & \\
\hline
\end{tabular}

\section{Introduction}

Curcuma caesia Roxb., commonly known as black turmeric is a wild species of the family Zingiberaceae. C. caesiais known especially in North East India and Bangladesh. It is rarely found in other parts of India, such as Madhya Pradesh, Jharkhand, Chattisgarh, and Orissa. The rhizomes have a high economical importance because of its putative medicinal properties. The rhizomes are used in the treatment of smooth muscle relaxant activity, haemorrhoids, leprosy, asthma, cancer, epilepsy, fever, wound, vomiting, menstrual disorder, anthelmentic, aphrodisiac, inflammation and gonorrhoeal discharges (Arulmozhi et al., 2006 and Sasikumar, 2005). The rhizomes are aromatic and yield an essential oil. The inner part of the rhizome is bluish-black in colour and emits a characteristic sweet smell due to the presence of essential oil. A paste made from the rhizome is used to cure blood dysentery and as poultice in rheumatic pain. The leaves are used as a wrapping material and dry leaves are used as fuel by Bengalis in Bangladesh (Yusuf et al., 2002). Northern tribes use Black Turmeric as a talisman to keep the evil spirits away, while in West Bengalit is an important place in traditional system of 
medicine and is also used as a substitute for turmeric in fresh state, in Madhya Pradesh also the plant is regarded as very auspicious and it is stated that a person who possesses it will never experience shortage of cereals and food (Pandey and Chowdhury, 2003).This clearly states that this plant is not only important medicinally but also important socially as well as spiritually.

Due to its high rare value, the plant is gradually getting in great demand in all over the world, but rarely available. It is an endangering species under fast dying out and thus needs to be conserved for future generations. It is the most rare and costliest rhizome in the Curcuma family. This species is found in the eastern Himalayas and inhabits warm forest areas. It can withstand temperatures $15-40^{\circ} \mathrm{C}$. It grows best in sandy or pebbly, loamy soil that is moist. Hence, this crop is introduce and grown in this areas in a natural way. The cultivation and harvest practices are similar to that of common turmeric (Curcumalonga). This crop is highly used for medicinal purpose, hence there is need to standardize the organic production techniques. In organic production, mulching is an important component in the management practices of black turmeric. Planting of black turmeric is normally taken during summer season. In the dry months, mulching conserves the moisture in the soil and enhances soil temperature for proper germination of the rhizome. In addition, physical properties of soil and minimizing weed competition it checks weed growth as well as weeds between mulch strips can be controlled by an herbicide and enriches the fertility of the soil after decomposition. Further it prevents washing out of soil and nutrients during heavy rains (Randhawa and Nandpuri, 1969 and Mohanty 1977). Black turmeric accompaniments well in moist deciduous forest (Nandkarni, 1976). While under commercial cultivation, the crop require sufficient moisture for their entire growth period. The time and intensity of moisture stress during the sensitive phase decreases the photosynthesis with stunted growth resulting in drastic reduction in biological yields (Chitra et al., 2017). Adoption of micro irrigation may help to increase the irrigated area, productivity of crop and water use efficiency (Sivanappan, 1995). Thus for increasing the productivity of black turmeric the soil and water management is needed. Mulching had shown some positive effects in this regard. Keeping this in view, it was felt necessary to study the effect of different mulches during transplanting of black turmeric to conserve soil and water so that the growth and yield of black turmeric under drip irrigation can be improved.

\section{Materials and Methods}

The experiment was conducted at the College Orchard, Department of Spices and Plantation Crops, Horticultural College and Research Institute, Tamil Nadu Agricultural University, Periyakulam during $2019-20$. The field is located at $10^{\circ}$ Nlatitudeand $78^{\circ}$ Elongitude, with an elevation of $300 \mathrm{~m}$ above mean sea level. The soil of the experimental field was red sandy loam in texture. The mean annual rainfall was $869 \mathrm{~mm}$ and mean temperature was $27.2^{\circ} \mathrm{C}$. The single bud rhizome derived transplant of black turmeric was planted under coconut ecosystem. The experiment was laid out in a Randomized Block Design with five treatments and replicated at four times. The details of the treatments are as follows,

\begin{tabular}{|l|l|}
\hline $\mathbf{T}_{1}$ & $\begin{array}{l}\text { Silver colour plastic } \\
\text { mulch }\end{array}$ \\
\hline $\mathbf{T}_{\mathbf{2}}$ & Coir pith as mulch \\
\hline $\mathbf{T}_{\mathbf{3}}$ & Paddy straw as mulch \\
\hline $\mathbf{T}_{\mathbf{4}}$ & Dry grass as mulch \\
\hline $\mathbf{T}_{\mathbf{5}}$ & Control (without mulching) \\
\hline
\end{tabular}


Different materials to be used as mulch were spread on the crop immediately after transplanting as per treatments. In treatment $\left(\mathrm{T}_{1}\right)$, silver colour polythene sheet of $50 \mu$ thickness (200 gauge) was spread by giving cut in $60 \times 45 \mathrm{~cm}$ before transplanting and the transplants were planted in the cut holes. Paddy straw, dry grass and coir pith were spread on bed such as to form $5-10 \mathrm{~cm}$ thick layer. In control, no mulch was applied and weeding was done twice over the period of crop. The drip irrigation system was installed and operated daily to provide the sufficient moisture to the plants. Organic manures were applied in all the treatments and similar cultural practices of turmeric were adopted for all treatments. Growth parameters viz., plant height, number of leaves, number of tillers, leaf length and leaf breadth were recorded in the first week of January. The crop was harvested in the first week of February and yield per hectare was estimated. Observations on growth and yield parameters were recorded from ten plants in each replication and the mean were used for statistical analysis (Panse and Sukhatme, 1957).

\section{Results and Discussion}

The important growth traits like plant height, number of leaves and number of tillers influence the growth and productivity of the crop (Table 1 and Table 2). From the Table 1, it is revealed that the dry grass has the significant influence on plant growth and yield in comparison to paddy straw, coir pith, silver colour plastic sheet and without mulch (control). In this trial, the plant height varied significantly from 40.10 to $58.40 \mathrm{~cm}$. The plants mulched with dry grass recorded the highest plant height $(58.40 \mathrm{~cm})$ followed by the plants mulched with paddy straw $(45.00$ $\mathrm{cm})$. In case of number of leaves, the treatment $\mathrm{T}_{4}$ (dry grass as mulch) recorded the highest number of leaves (16.00) and the lowest number of leaves $(9.50 \mathrm{~cm})$ registered by the treatment $\mathrm{T}_{5}$ (without mulch). The number of tillers per plant responded significantly to different mulching materials. The use of dry grass, paddy straw, coir pith and plastic mulch responded tillers per plant increased to that of control (Table 1). The highest number of tillers per plant (5.10) was obtained in dry grass as mulch which was significantly different from control as well as other treatments. The lowest number of tillers per plant (2.30) was recorded in without any mulch. The leaf length and leaf width was statistically significant in different treatments (Fig. 1). The leaf length and leaf width were significantly higher in dry grass mulch $(35.40$ $\mathrm{cm}$ and $9.70 \mathrm{~cm}$ respectively) and followed by paddy straw mulch $(27.70 \mathrm{~cm}$ and $8.50 \mathrm{~cm}$ respectively). While the results obtained the without any mulch (control) was $19.60 \mathrm{~cm}$ and $6.40 \mathrm{~cm}$ respectively. Similarly, results in Table 2 and Figure 2 showed that number of rhizomes per plant and length of rhizome was significantly increased in dry grass mulch (13.34 and $7.56 \mathrm{~cm}$ respectively) followed by paddy straw mulch (11.26 and $6.63 \mathrm{~cm}$ respectively), whereas the yield component characters was decreased in without mulch (8.45 and $4.93 \mathrm{~cm}$ respectively). Among various treatments, the highest fresh rhizome yield $\left(22.03 \mathrm{t} \mathrm{ha}^{-1}\right)$ was recorded under treatment $\mathrm{T}_{4}$, which increased by 17 per cent over control. The low yield was recorded under control i.e., without mulch (12.73 t ha $\left.{ }^{1}\right)$. Mulching with dry grass in black turmeric field have recorded significantly higher rhizome yield over mulching with coir pith and silver colour plastic sheet.

A good mulching material with adequate supply of nutrients is essential for plants to attain maximum production. It was observed from this experiment that mulching effectively regulates soil temperature and preserves soil water (Iqbal et al., 2006). The effect of mulch on the plant height was 
significant and the number of leaves increased steadily over the season. The increased leaf growth under dry grass mulch was attributed to the fact that grass mulch reduces runoff following decomposition; therefore, soil structure is likely to benefit from the use of organic mulches (Feldman et al., 2000). The effect of mulchon the number of tillers was significant throughout growing period when plants under grass mulch. Grass mulch could have promoted tiller development due to the decomposed organic matter optimizing water use efficiency, and enhancing root and shoot growth. Changes in root zone temperature can affect the uptake and translocation of essential nutrients, therefore influencing root and shoot growth of crops (Chu et al., 2016). The observed enhancement on tillers with types of mulches might also beat tributed to the benefits of organic mulches which lead to increased organic matter to the soil, reduced water loss, and reduced soilerosion (Chu et al., 2016) leading to the promotion of vegetative growth, which positively reflects on tillers. Soil temperature can be adjusted with the use of mulches. Mulches reduce soil evaporation and increase yield through increasing water use efficiency (Adekalu et al., 2006). Mulches on the soil surface reduce evaporation, increase water infiltration, control soil erosion as well as improving soil structure; thus affecting plant growth and yield affect (Bakshi et al., 2015).

Table.1 Effect of Mulching on growth parameters of Black turmeric

\begin{tabular}{|c|c|c|c|c|c|c|}
\hline Treatment & $\begin{array}{c}\text { Plant } \\
\text { height }(\mathbf{c m})\end{array}$ & $\begin{array}{c}\text { No. of leaves / } \\
\text { plant }\end{array}$ & $\begin{array}{c}\text { No. of } \\
\text { tillers / } \\
\text { plant }\end{array}$ & $\begin{array}{c}\text { Leaf } \\
\text { length } \\
\text { (cm) }\end{array}$ & $\begin{array}{c}\text { Leaf breadth } \\
\text { (cm) }\end{array}$ & $\begin{array}{c}\text { Days to } \\
\text { maturity }\end{array}$ \\
\hline $\mathbf{T}_{\mathbf{1}}$ & 43.40 & 10.60 & 2.50 & 24.60 & 6.70 & 265.00 \\
\hline $\mathbf{T}_{\mathbf{2}}$ & 44.10 & 12.40 & 3.00 & 24.80 & 7.30 & 268.00 \\
\hline $\mathbf{T}_{\mathbf{3}}$ & 45.00 & 13.20 & 3.60 & 27.70 & 8.50 & 262.00 \\
\hline $\mathbf{T}_{\mathbf{4}}$ & 58.40 & 16.00 & 5.10 & 35.40 & 9.70 & 258.00 \\
\hline $\mathbf{T}_{\mathbf{5}}$ & 40.10 & 9.50 & 2.30 & 19.60 & 6.40 & 270.00 \\
\hline Mean & $\mathbf{4 6 . 2 0}$ & $\mathbf{1 2 . 3 4}$ & $\mathbf{3 . 3 0}$ & $\mathbf{2 6 . 4 2}$ & $\mathbf{7 . 7 2}$ & $\mathbf{2 6 4 . 6 0}$ \\
\hline $\mathbf{S E d}$ & $\mathbf{1 . 0 2}$ & $\mathbf{0 . 2 2}$ & $\mathbf{0 . 0 7}$ & $\mathbf{0 . 4 1}$ & $\mathbf{0 . 2 0}$ & - \\
\hline $\mathbf{C D}(\mathbf{0 . 0 5 \%})$ & $\mathbf{2 . 1 6}$ & $\mathbf{0 . 4 7}$ & $\mathbf{0 . 1 5}$ & $\mathbf{0 . 8 8}$ & $\mathbf{0 . 4 3}$ & - \\
\hline & & & & & & \\
\hline
\end{tabular}

Table.2 Effect of Mulching on yield parameters of Black turmeric

\begin{tabular}{|c|c|c|c|c|c|}
\hline Treatment & $\begin{array}{c}\text { No. of rhizome } \\
\text { / plant }\end{array}$ & $\begin{array}{c}\text { Length of } \\
\text { rhizome }(\mathbf{c m})\end{array}$ & $\begin{array}{c}\text { Fresh rhizome } \\
\text { yield/plant } \mathbf{( g )}\end{array}$ & $\begin{array}{c}\text { Fresh rhizome yield/plot } \\
\text { (3 sq. m) } \mathbf{( k g )}\end{array}$ & $\begin{array}{c}\text { Estimated fresh } \\
\text { rhizome yield/ha (t) }\end{array}$ \\
\hline $\mathbf{T}_{\mathbf{1}}$ & 10.78 & 5.52 & 249.67 & 4.99 & 18.48 \\
\hline $\mathbf{T}_{\mathbf{2}}$ & 10.01 & 5.14 & 224.00 & 4.48 & 16.58 \\
\hline $\mathbf{T}_{\mathbf{3}}$ & 11.26 & 6.63 & 262.33 & 5.25 & 19.41 \\
\hline $\mathbf{T}_{\mathbf{4}}$ & 13.34 & 7.56 & 297.67 & 5.95 & 22.03 \\
\hline $\mathbf{T}_{\mathbf{5}}$ & 8.45 & 4.93 & 172.00 & 3.44 & 12.73 \\
\hline Mean & $\mathbf{1 0 . 7 7}$ & $\mathbf{5 . 9 6}$ & $\mathbf{2 4 1 . 1 3}$ & $\mathbf{4 . 8 2}$ & $\mathbf{1 7 . 8 4}$ \\
\hline $\mathbf{S E d}$ & $\mathbf{0 . 2 2}$ & $\mathbf{0 . 1 1}$ & $\mathbf{1 . 8 5}$ & - & - \\
\hline $\mathbf{C D}(\mathbf{0 . 0 5 \%})$ & $\mathbf{0 . 4 9}$ & $\mathbf{0 . 2 5}$ & $\mathbf{6 . 2 3}$ & - & - \\
\hline
\end{tabular}


Fig.1 Effect of different mulches on growth parameters of Black turmeric

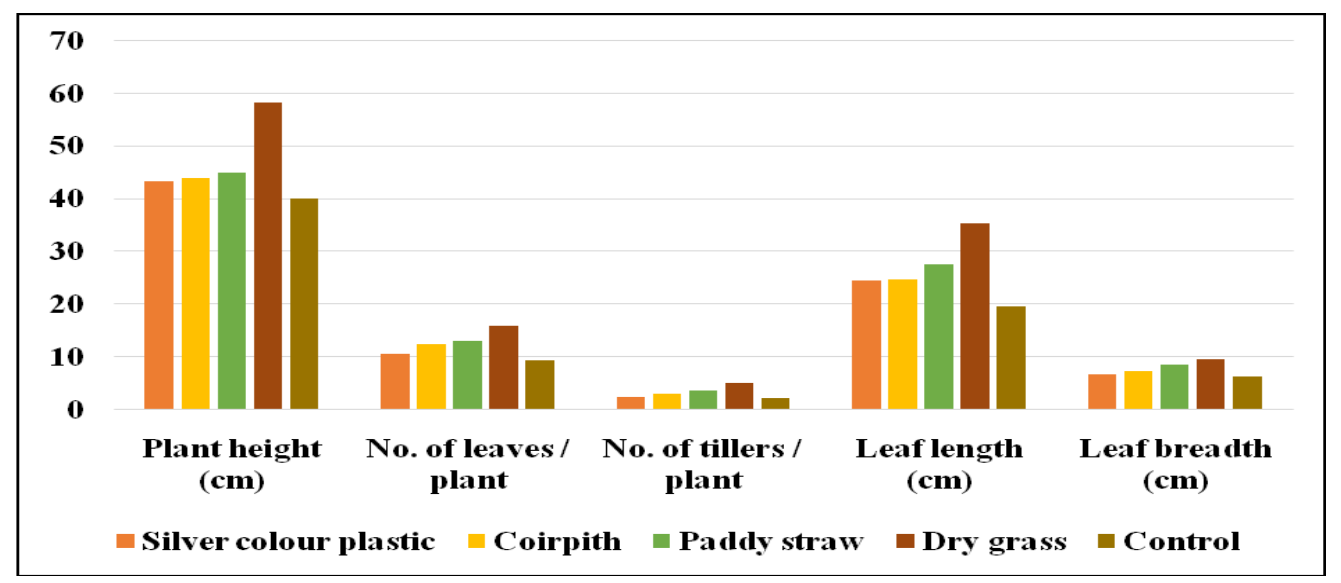

Fig.2 Effect of different mulches on yield parameters of Black turmeric

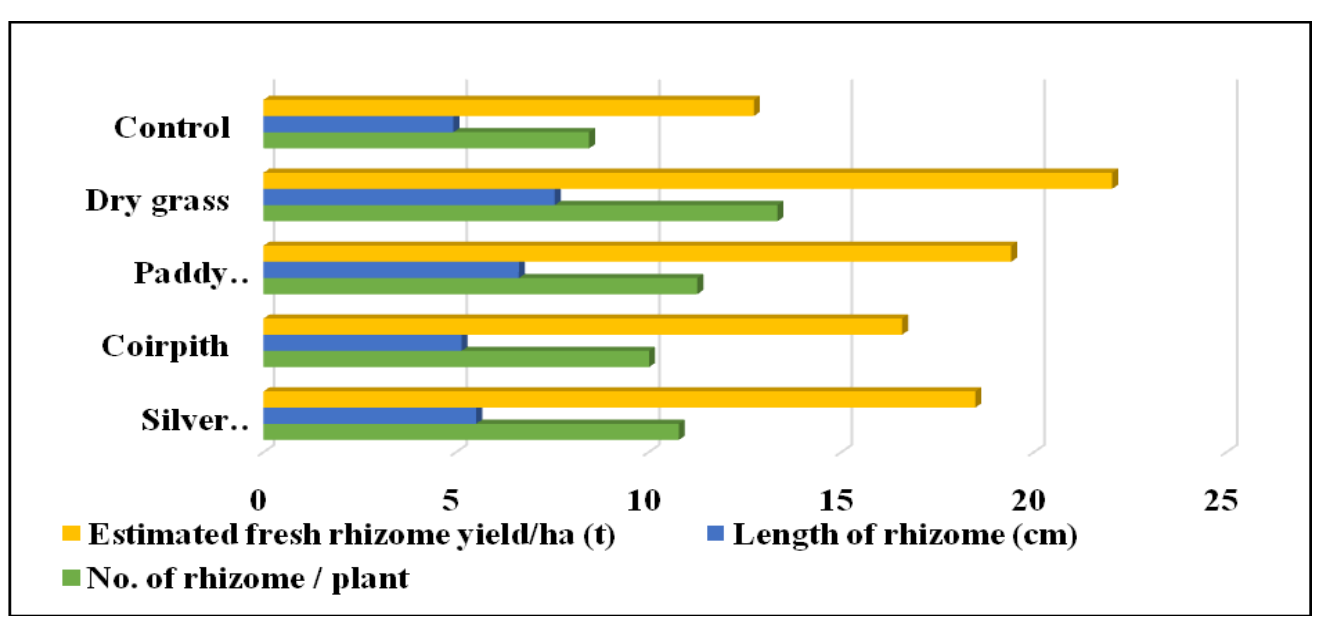

Fig.3 Field view of different mulches in black turmeric field

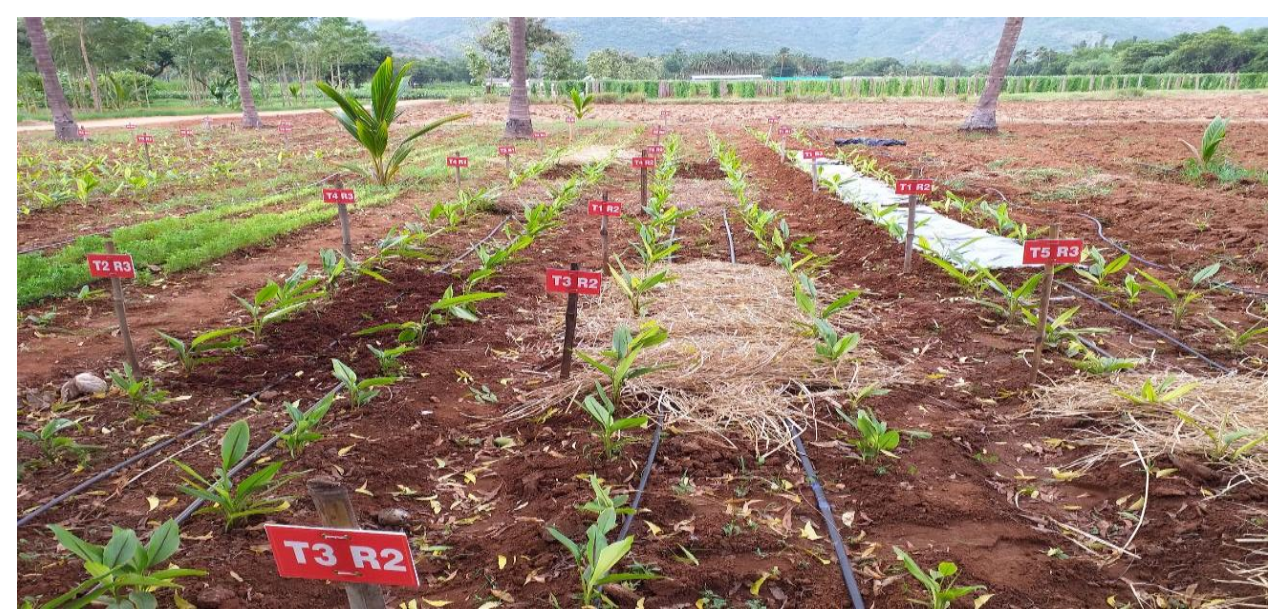


Fig.4 Best treatment - Dry grass as mulch

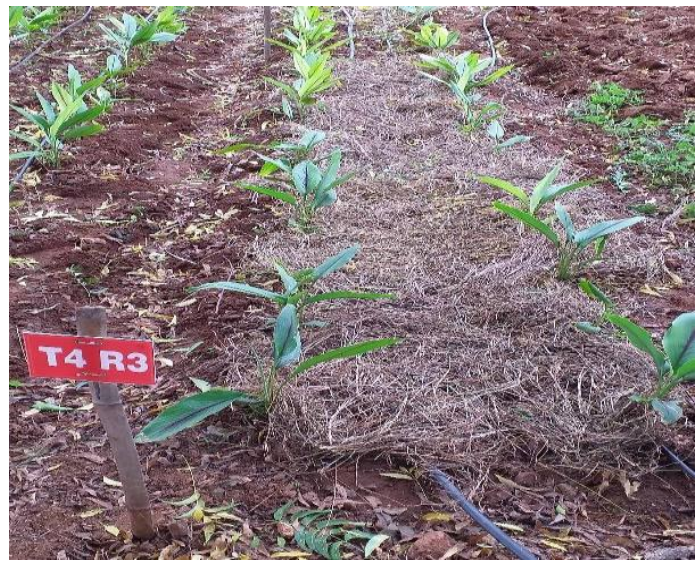

The yield data presented in Table 2 shows that the yield of black turmeric crop was also statistically significant under different treatment. Maximum yield of $\left(22.03 \mathrm{t} \mathrm{ha}^{-1}\right)$ in dry grass mulch followed by paddy straw mulched crop was $19.41 \mathrm{t} \mathrm{ha}^{-1}$. These two treatments were found as better treatments when compared with other treatments. These results were in accordance with the findings of Annu Verma and Sarnaik (2006) in turmeric, Khan et al., (2005) in tomato, Thakur et al., (2000) in capsicumand Mohanty et al., (1977) in ginger. The improvement of yield might be related to the elevated soil temperature and the quality of radiation under the cover. Similar results were obtained by Wang et al., (2002). Sharma et al., (2008) reported that grass cover significantly improved plant physiology, growth and yield. They concluded that berry weight and yield were the highest in plants grown under grass and black plastic mulch. Ibara et al., (2001) found similar results on growth of muskmelon. Groszmann (1954) also reported uniform germination by mulching which corroborates with these findings. Also mulches facilitated in better mineralization and availability of nutrients in modifying the various yields attributes to the better advantage of rhizome yield.

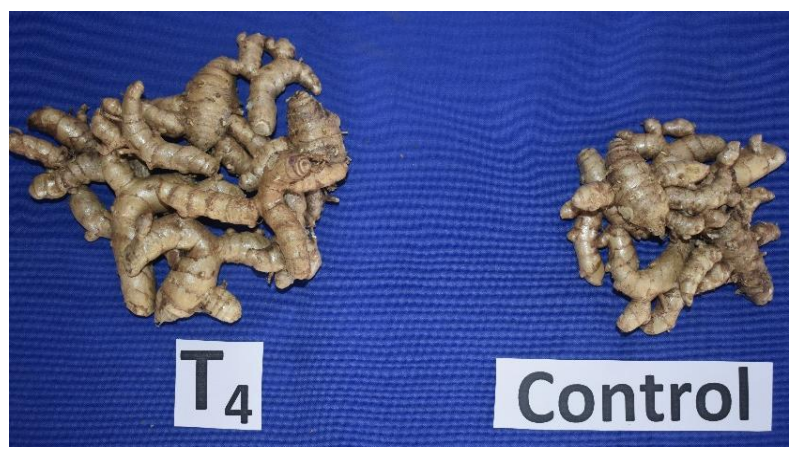

The study showed that mulches help in water conservation in black turmeric production, the dry grass mulch promotes increase in plant growth, which is reflected in the yields thus dry grass mulch should be used for better rhizome yield.

\section{Acknowledgement}

The author is grateful to the Project Regional Director, NMPB-Regional cum Facilitation Centre (Southern Region), Kerala Forest Research Institute, Peechi, Kerala for the financial assistance under GOI-NMPB scheme.

\section{References}

Adekalu, K.O., Okunade, D.A. and Osunbitan, J.A. 2006. Compaction and mulchingeffects on soil loss and runoff from twoSouthWestern Nigeria agricultural soils.Geoderma. 137: 226230.

AnnuVermaand Sarnaik,D. A. 2006. Effect of different types of mulches on growthand yield of turmeric (Curcuma longa. L.). International Journal of Agricultural Science.2(2): 425-426

Arulmozhi, D.K., Sridhar, N.,Veeranjaneyulu, A. and Arora, K.S. 2006. Preliminary mechanistic studies on thesmooth muscle 
relaxant effect of hydroacloholic extract of Curcumacaesia. Journal of Herbal Pharmacotherapy. 6: 3 - 4

Bakshi, P., Wali, V. K., Iqbal, M., Jasrotia, A.,Kour, K., Ahmed, R. and Bakshi, M.2015. Sustainable fruit production bysoil moisture conservation with differentmulches: A review. African Journal ofAgricultural Research. 10(52): 4718-4729.

Chitra, R.,Havaraddi, R. M., Subramanian,S. and Suresh, J. 2017. Effect of scheduling of drip irrigation on growth, yield and water use efficiency of turmeric (Curcuma longa L.) var. CO 2. Journal of Spices and Aromatic Crops.26(1): 8-15

Chu, Q., Sha, Z., Nakamura, T., Oka, N., Osaki, M. and Watanabe, T. 2016. Differential responses of soybean and sorghum growth, nitrogen uptake, and microbial metabolism in the rhizosphere to cattle manure application: A rhizobox study. Journal of Agricultural and Food Chemistry. 64(43): 8084-8094.

Feldman, R.S., Holmes, C. E. and Blomgren, T. A.2000. Use of fabric and compost mulches for vegetable production in low tillage, permanent bed system: Effects oncrop yield and labour. American Journalof Alternative Agriculture. 15(4): 146-153.

Groszmann, H. M. 1954. Ginger production. Advances in Agricultural Journal. 78: 259-62.

Ibara, L., Flores, J. and Diaz-Perez, J.C. 2001. Growth and yield of muskmelon inresponse to plastic mulch and rowcovers. Scientia Horticulture. 87:13914.

Iqbal, M.A., Hassan, A. and Aziz, T. 2006. Effect of mulch, irrigation and soil type on nutrient uptake of forage maize. Pakisthan Journal of Agricultural Sciences. 43(1-2):13-16.

Khan, M. H., Chattha, T. H., and Hayat, R. 2005. Growth and yield response of tomato (Lycopersicon esculantum L.) to organic and inorganic mulch. Asian journal of plant science 4(2): 128-131
Mohanty, D. C. 1977. Studies on the effect ofdifferent mulch materials on the performance of ginger in the hills of Pottangi. Orissa Journal of Horticulture. 5: 11-17.

Nandkarni, K.M. 1976. Indian Medical. Medica. Vol Bombay:Popularprakashan,pp- 414

Pandey A.K. and Chowdhary A.R. 2003. Volatile constituents of rhizome oil of CurcumaCaesia. Flavour and Fragrance Journal. 18:463-465.

Panse V.G. and Sukatme P.V. 1957. Statistical methods for Agricultural Workers. Second Edition. pp. 152-157.

Randhawa, K. S. and Nandpuri, K. S. 1969. Grow ginger in your kitchen garden. Progressive Farming. 5: 6- 7

Sasikumar, B. 2005. Genetic resource of Curcuma: diversity, characterization and utilization. Plant Genet Resource. 3:230251

Sharma, R., Singh, R. D.and Gupta, R.K. 2008. Influence of row covers and mulching interaction on leaf physiology, fruit yieldand albinism incidence in sweet Charlie strawberry (Fragaria x ananasaDuch).Fruits. 63:103-110.

Sivanappan, R. K. 1995. Status on the use of micro irrigation system in crop production. Micro irrigation and fertigation. (ed). K. Shivashankar, UAS, Bangalore, p: 16-25.

Thakur, P. S., Thakur, A.,Kanaujia, S. P. and Thakur, A. 2000. Reversal of water stress effects. Mulching impact on the performance of Capsicum annuum under water deficit. Indian Journal of Horticulture.57: 250-254.

Wang, S.Y., Zheng, W. and Galleta, G.J. 2002.Cultural system affects fruit quality andantioxidant capacity in strawberries. Journal of Agricultural and Food Chemistry. 50:6534-6542.

Yusuf, M., Rahman, M. A., Chowdhury, J. U. and Begum, J. 2002. Indigenous knowledge about the use of Zingibers in Bangladesh. J. Econ. Taxon. Bot. 26: 566-570. 


\section{How to cite this article:}

Chitra, R., D. Janaki and Jansirani, P. 2020. Effect of Different Types of Mulches on Growth and Yield of Black Turmeric (Curcuma caesia). Int.J.Curr.Microbiol.App.Sci. 9(07): 28172824. doi: https://doi.org/10.20546/ijcmas.2020.907.333 